\title{
RURAL TERRITORIES OF KAZAKHSTAN: REALITIES, PROBLEMS AND SOLUTIONS
}

\author{
ҚАЗАҚСТАННЫҢ АУЫЛДЫҚ АУМАҚТАРЫ: ШЫНДЫҚТАР, МӘСЕЛЕЛЕР \\ ЖӘНЕ ОЛАРДЫ ШЕШУ ЖОЛДАРЫ
}

\section{СЕЛЬСКИЕ ТЕРРИТОРИИ КАЗАХСТАНА: РЕАЛИИ, ПРОБЛЕМЫ И ПУТИ ИХ РЕШЕНИЯ}

\author{
B. KALYKOVA \\ C.E.Sc., Associated Professor \\ Kazakh National Agrarian University, Almaty, Kazakhstan \\ kalykova_b_b@mail.ru \\ Б.Б. КАЛЫКОВА \\ э.Ғ.К., доцент \\ Қазақ ұлттық аграрлық университеті, Алматы, Қазақстан \\ Б.Б. КАЛЫКОВА \\ к.э.н., доцент \\ Казахский национальный аграрный исследовательский университет, \\ Алматы, Казахстан
}

\begin{abstract}
The study deals with the formation of a model of sustainable and effective development of agriculture and rural areas as the main task of implementing the State agricultural policy. The relevance of the tasks set by the author lies in considering the living conditions in the countryside as an integrated approach to the country's economy in order to diversify the types of activities in rural areas, create new sources of income. The directions representing a new economic paradigm of rural development in Kazakhstan are justified. The ways of implementing a comprehensive policy are shown, which consists in the partnership of public structures, local governments, public organizations and private sector, so that in the future, rural areas will become the most important socioeconomic and ecological subsystem of society. One of the key issues in the development of a model of modernization of the Kazakh countryside - the methodology for assessing the strategy and taken measures are highlighted. It is noted that monitoring of a wide variety of regional situations in rural settlements is of great scientific importance in creating a reliable and objective basis for developing substantiated measures to improve the quality of life of the rural population and determining priorities. The author states that the implementation of the "Auyl - El besigi" program contributes to the development of support and satellite villages, which have the potential to increase the level of life and well-being of rural residents, modernize the social infrastructure of the SNP JSC "Fund for Financial Support of Agriculture" allocated significant amounts to ensure employment of the rural population. The program condition in the funded projects should be startups, proposals for non-agricultural areas of expansion of activities in rural areas.
\end{abstract}

Аңдатпа: Зерттеу мемлекеттік аграрлық саясатты іске асырудың негізгі міндеті ретінде ауыл шаруашылығы мен ауылдық аумақтарды тұрақты және тиімді дамыту моделін қалыптастыруға арналған. Автор қойған міндеттердің өзектілігі - ауылдық жерлердегі қызмет түрлерін әртараптандыру, жаңа табыс көздерін құру мақсатында ел экономикасына интеграцияланған тәсіл ретінде ауылдағы өмір сүру жағдайларын қарастыруда. Қазақстанның ауылдық дамуының жаңа экономикалық парадигмасын білдіретін бағыттар негізделген. Перспективада ауылдық аумақтар қоғамның аса маңызды әлеуметтік-экономикалық және экологиялық кіші жүйесіне айналуы үшін мемлекеттік құрылымдардың, жергілікті өзінөзі басқару органдарының, қоғамдық ұйымдар мен жеке сектордың әріптестігінен тұратын кешенді саясатты іске асыру жолдары көрсетілген. Қазақстандық ауылды жаңғырту моделін әзірлеудегі басты мәселелердің бірі - стратегияны бағалау және қабылданатын шаралар әдіснамасы айқындалды. Ауылдық елді мекендердегі өңірлік жағдайлардың алуан түрлілігін мониторингтеудің ауыл халқының өмір сүру сапасын жақсарту және басымдықтарды айқындау жөніндегі негізделген шараларды әзірлеу үшін сенімді және объективті база құруда маңызды ғылыми мәні бар екендігі атап өтілді. Автор "Ауыл - Ел бесігі" бағдарламасын іске асыру ауыл тұрғындарының өмір сүру деңгейі мен әл-ауқатын 
арттыру, АEM әлеуметтік инфрақұрылымын жаңғырту мақсатында әлеуеті бар тірек және спутниктік ауылдарды дамытуға ықпал ететінін атап өтті. "Ауыл шаруашылығын қаржылай қолдау қоры" АҚ ауыл халқын жұмыспен қамтамасыз ету үшін қомақты қаражат бөлді. Қаржыландырылған жобалар қатарында бағдарламаның шарты стартаптар, ауылдық аумақтардағы қызметті кеңейтудің ауыл шаруашылығына жатпайтын бағыттары бойынша ұсыныстар болуға тиіс.

Аннотация. Исследование посвящено формированию модели устойчивого и эффективного развития сельского хозяйства и сельских территорий как основной задачи реализации государственной аграрной политики. Актуальность поставленных автором задач - в рассмотрении условий проживания на селе как интегрированного подхода к экономике страны с целью диверсификации видов деятельности в сельской местности, создания новых источников доходов. Обоснованы направления, представляющие новую экономическую парадигму сельского развития Казахстана. Показаны пути реализации комплексной политики, заключающейся в партнерстве государственных структур, органов местного самоуправления, общественных организаций и частного сектора с тем, чтобы в перспективе сельские территории стали важнейшей социально-экономической и экологической подсистемой общества. Выделен один из ключевых вопросов при разработке модели модернизации казахстанского села - методология оценки стратегии и принимаемых мер. Отмечается, что мониторинг большого разнообразия региональных ситуаций в сельских населенных пунктах имеет важное научное значение в создании надежной и объективной базы для разработки обоснованных мер по улучшению качества жизни сельского населения и определения приоритетов. Автор констатирует, что реализация программы «Ауыл - Ел бесігі» способствует развитию опорных и спутниковых сел, имеющих потенциал с целью повышения уровня жизнедеятельности и благосостояния жителей сельской местности, модернизации социальной инфраструктуры СНП. АО «Фонд финансовой поддержки сельского хозяйства» направил значительные суммы для обеспечения занятости сельского населения. Условием программы в числе профинансированных проектов должны быть стартапы, предложения по несельскохозяйственным направлениям расширения деятельности в сельских территориях.

Key words: rural areas, region, production, products, technologies, entrepreneurship, priorities, population, strategy, measures, level and quality of life, potential.

Түйінді сөздер: ауылдық аумақтар, аймақ, өндіріс, өнім, технология, кәсіпкерлік, басымдықтар, халық, стратегия, шаралар, өмір сүру деңгейі мен сапасы, әлеует.

Ключевые слова: сельские территории, регион, производство, продукция, технологии, предпринимательство, приоритеты, население, стратегия, меры, уровень и качество жизни, потенциал.

Introduction. The country's food security is based on the stable progressive development of the agro-industrial complex. Its prerequisite is the reproduction of labor and land resources, which is impossible without sustainable development of rural areas.

Rural areas of the country have unique natural, demographic, economic, historical and cultural potential, which, if effectively used, can ensure sustainable development, a high level and quality of life of the population. Despite the powerful potential, rural areas are currently experiencing a systemic crisis, manifested in the deterioration of the demographic situation in rural areas, low living standards and high unemployment rates of the rural population, a decrease in the quality of life in rural areas, and the destruction of the evolutionary system of rural settlement [1].

In recent years, Kazakhstan has been undertaking a number of measures aimed at sustainable, more dynamic rural development. The State Program on Development of AgroIndustrial Complex of the Republic of Kazakhstan for 2017-2021 is being implemented, this is a program for the development of agriculture in Kazakhstan, the main goals of which are the effective development of rural areas through strengthening the social sphere, increasing employment and living standards of the rural population. Unfortunately, in most territories the necessary indicators for agricultural production, stabilization of demographic situation, and improvement in the quality of life of villagers have not yet been achieved. Attention to this problem is associated with a decrease in the number of population living in rural areas; a decrease in indicators of the level and quality of life in the countryside, with a slightly narrowing gap in these indicators in the city and in the countryside. 


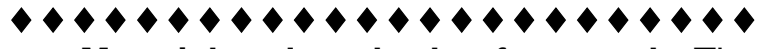

Material and methods of research. The main reasons for this situation are the lack of resources; no in-depth analysis of the differentiation of the natural-economic and sociodemographic conditions of individual rural areas and their opportunities for selfdevelopment is carried out; the development of a strategy and development programs is carried out formally according to a single template without revealing the features of the programming object; the content of the programs needs to be improved, since they are often not supported by the necessary calculations and scientific and methodological support [2].

In the EU countries, the solution of problems in rural areas is a priority task. Suffice it to say that about half of the EU budget expenditures go to the development of agriculture and rural areas. They direct the policy of development of rural regions to increase the level of their competitiveness in order to increase the contribution to the development of the national economy, to create for the rural population a standard of living comparable to the urban one, to protect natural resources and cultural heritage.

The socio-economic development of rural areas of the Republic of Kazakhstan is largely determined by the size and degree of use of the potential concentrated in this area. $47 \%$ of the population lives in the rural areas of the country, more than $40 \%$ of the best fertile lands are under the jurisdiction of land users of rural settlements [3].

Results and their discussion. Almost one quarter of the country's territory is characterized as steppe lands, half as semi-desert and desert territories, and the remaining quarter of the territory is foothill. $80 \%$ of the country's territory is characterized as agricultural land, which is more than 200 million hectares. However, only $40 \%$ of this territory, or 96 million hectares, is used in agricultural turnover. Large fluctuations in yield in some years are observed not only due to adverse weather conditions, but also due to the relatively low technological equipment of the industry in almost all production stages, including postharvest processes. The processing and selling of products on both local and foreign markets also require improvement. For example, only $2-3 \%$ of the total volume of vegetable and fruit production is processed in the country. However, despite the relatively low share of agricultural processing, Kazakhstan is one of the largest producers and exporters of certain types of products such as cereals and flour. In terms of flour exports, the country occupies a leading position on the world market.
The agricultural sector, as shown by world and domestic practice, remains a highrisk and low-profit sector of economy. According to official statistics, about one-third of rural residents have incomes below the subsistence level. On general background of economic growth, there is still a significant disparity in the standard of living of urban and rural populations, and significant regional differences in income. The low level of agricultural technologies and technologies for processing agricultural products is the main reason for the lack of competitiveness of domestic products in the world and domestic markets, reduced potential income in the agricultural sector.

Further existence of this condition increases the differentiation of the country's population in terms of living standards, and negatively affects the socio-political atmosphere of society, human development indicators and the investment image of the country.

Rural development is an integrated approach to the rural economy in order to diversify rural activities and create new sources of income and jobs outside of agricultural production. This approach represents a new economic paradigm of rural development in $\mathrm{Ka}$ zakhstan. According to the world experience, the implementation of a comprehensive rural development policy requires close partnership and coordinated efforts of government agencies, local governments, public organizations and private sector. In the future, the focus of agricultural policy will shift to rural development [4].

One of the key issues in the development of the model of rural development of the Republic of Kazakhstan is the methodology for assessing agricultural policy, strategy and measures taken. Although assessment is sometimes understood as an external aspect of policy, it can only be used effectively when it is an integral part of the decision-making process for rural development [5]. Monitoring in an exceptionally wide variety of regional situations in rural areas of Kazakhstan has important educational and scientific significance. Its main task, which is purely practical, is to create a reliable and objective basis for developing a sound State policy for regulating the development of rural territories and determining its priorities, taking measures of selective public support for certain territories that are adequate to the essence of the specific regional problems and prospects identified during monitoring.

The geographical location reflects the corresponding need for transport costs. The remoteness of rural localities also affects the 


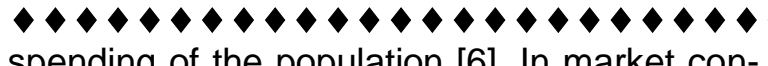

spending of the population [6]. In market conditions, the price of goods and services is higher the greater the distance to their destination, i.e. the prices of goods and services in rural areas are usually higher than in cities. Kazakhstan has huge territories, each region and even district has its own specific features, which are manifested in the level of profitability, the difference in the types of products consumed and their quality, the share of products of a high degree of readiness, etc. the following group includes the individual conditions of an individual rural family: housing conditions, working hours, the size of a personal subsidiary farm, etc.

The difficulties of household's work in rural areas are associated with a low level of public services, the need to process the products of personal subsidiary farms on their own, and the low availability of cultural and household items for rural families.

Based on the above, social policy aimed at improving the quality of life of the population should include: an effective demographic vector; creating conditions for the development of human capital, reducing poverty and increasing employment; expanding opportunities for participation in all spheres of public life.

The positive aspects include the increased funding for social sectors, which allows the construction of a number of modern facilities and their overhaul, improvement of material and technical equipment and introduction of new technologies in the industry, creation of the effective regulatory framework for social reforms.

As part of the Strategy of Kazakhstan's entry into the top fifty most competitive countries in the world, agricultural sector of the country should solve the important task of increasing the competitiveness of human capital to achieve effective parameters of human capital in solving socio-demographic problems, which can be grouped as follows:

- the quality of human capital decreases due to the deterioration of public health, formalization of access to social services;

-there is a structural distortion of education and health care, which is expressed in the discrepancy between the real needs of society;

-in the regions, there are weak mechanisms for influencing the competitiveness of human capital, which significantly reduces the effectiveness of financing public expenditures;

-existing territorial disparities are becoming more pronounced in the form of special anomalies, the alignment of which requires significant funds to achieve the desired result;

-social needs of territories and opportunities to meet them require a special approach to the use and application of indicators of socio-demographic development.

The main indicators of the State Program on Development of Regions for 2020-2025 include the increase in the level of urbanization. If in 2015 the level of urbanization was above $56 \%$, in 2019 it is $58.2 \%$. With the implementation of the program in the first 5 years, water supply has significantly improved not only in cities, but also in rural areas. The level of provision with centralized water supply in cities has reached $94.5 \%$, and in rural areas - almost $60 \%$. This work continues within the framework of the "Nurly Zher" program since 2020.

A separate priority within the framework of "Auyl-El besigi" is the development of reference and satellite villages that have the potential for development in order to improve the quality of life and improve the well-being of our citizens. This program is aimed at improving the quality of life of rural residents and modernizing the social infrastructure of rural localities.

Of the 6.5 thousand villages in the country, about 3.5 thousand have been identified, of which 1150 are support villages, the rest are satellite and border villages, which also have development potential. The project will work for 7 years, which will allow for the modernization of all social and engineering infrastructure in these localities until 2027. It is expected that by 2027 , approximately $90 \%$ of the rural population will live in these rural localities, meaning that 7 million people will be provided with high-quality social and engineering infrastructure. About 900 billion tenge will be allocated over 7 years for the development of social and engineering infrastructure for the life of the population: reconstruction of the water supply network, power supply network, etc. activities of the population.

Over three years, 160 billion tenge has been allocated through the "Fund for financial support of agriculture" JSC for lending projects under the Enbek program. With this money, more than 53 thousand people are employed. A special condition of the Enbek program is that $20 \%$ of the number of funded projects should be start-UPS, $20 \%$ - nonagricultural projects in rural areas. The Fund finances projects on animal husbandry, crop production, storage and processing of agricultural products, and development of entrepreneurship in rural and urban areas.

Preferential micro loans are provided for a period of up to 6.5 years at a rate of $6 \%$ per annum, the effective interest rate is not more than $6.7 \%$ per annum, the average size of a micro loan is 4 million tenge. A grace period is provided for the payment of principal and re- 


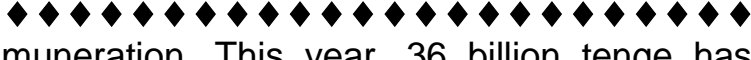
muneration. This year, 36 billion tenge has been allocated for these purposes through the Fund for Financial Support to Agriculture.

As part of the implementation of the new program until 2025, activities are planned in the regions to form "centers" of economic growth and increase competitiveness and managed urbanization as a global trend. In the developed countries of the OECD, the average level of urbanization is about $77 \%$, in Kazakhstan in $201958.2 \%$, but by 2025 it is planned to reach $62 \%$ of managed urbanization. Finance, human capital, and investment are concentrated in cities. The new program assumes certain growth points, first of all, these are 4 large agglomerations, 14 urbanized zones, including regional centers and Semey, mono and small cities. In addition, efforts will be directed to the development of reference and satellite villages with development potential. Budget investments will be directed to these areas, and private investment will be attracted for the dynamic development of all regions. Major cities will become points of attraction.

As of January 1, 2020, 446.7 thousand legal entities were registered in Kazakhstan. Over the past year, their number has increased by more than 12.9 thousand units. Growth has continued for at least 10 years in a row: even in difficult years for the economy of the Republic, legal entities have become more numerous. Compared to the beginning of 2010, their total number has increased by one and a half times (from 298 thousand). More than $98 \%$ of them are small businesses, the share of which is growing along with the number of registrations. Only in 2019, the number of subjects increased by 13.2 thousand units, almost reaching 438 thousand.

With the development of small businesses in increasing employment in rural areas, there are high expectations. This is explained not only by the need to make better use of the potential of rural labor resources in economic sectors, but also by the large outflow of the working-age population from the countryside to the city.

A characteristic feature of small business is secondary employment, i.e. in addition to permanent employees, the involvement of part-time and temporary workers. Its development in rural areas contributes to the expansion of production of existing structures and the creation of jobs in new enterprises.

In the field of agriculture, small business is characterized by the development of peasant (private) farms, in other areas-the growth of individual entrepreneurship (independent legal entities as self-employed or employers). Small businesses in rural areas can relate not only to agriculture, but also to other areas of activity: storage, processing and marketing of agricultural products; wood harvesting and woodworking, production of building materials and construction; folk crafts and crafts; consumer services; collection of medicinal plants and other natural raw materials; rural tourism, etc.

It is known that the level of well-being of the rural population, based on the total volume of consumption, is determined by the employment of rural residents, the degree of participation of the able-bodied population in socially useful work. Therefore, it is necessary to take measures to reduce the outflow and create permanent qualified personnel by increasing wages and developing a competitive sphere in rural areas. At the same time, the development of entrepreneurship makes it possible to find ways to support the population for effective employment. Small business is a flexible and powerful tool for solving a whole range of economic and social problems: from saturation of the market with a variety of goods and services, ensuring employment of the rural population by creating jobs, creating a healthy competitive environment.

The labor market in the agro-industrial complex and rural employment occupy a key place in the national labor market, the formation and development of which is influenced, on the one hand, by the international labor market, on the other, by the current situation in the economy [7]. The relevance of this problem for the Republic is explained by the fact that $40 \%$ of its population lives in rural areas, for many agricultural production is a decisive factor that determines their lifestyle and mentality.

The main reasons for this rather difficult situation - the remoteness of rural areas from markets, raw materials, agricultural machinery and sales of agricultural products; undeveloped production and social infrastructure, in this respect, limited investment opportunities and creation of additional jobs; lack of jobs offered by the employment Center, and the inadequacy of their education and training for unemployed; unemployed weak adaptation to market conditions and their transition into the informal sector of the economy.

The decline in employment opportunities is also due to the limited mobility of rural residents, and sometimes the reluctance of people to take up available jobs. Moreover, the lack of a sufficient number of qualified personnel, the attraction of foreign labor and the predominance of shift work methods in the organization of production contributed to an increase in the unemployment rate in many rural areas of the Republic. 
$\bullet \bullet \bullet \bullet \bullet \bullet \bullet \bullet \bullet \bullet \bullet \bullet \bullet \bullet \bullet \bullet \bullet \bullet \bullet \bullet$

Thus, the deep differences in the demographic structure of the population in certain regions of the Republic require a differentiated approach when developing a regional strategy for socio-economic transformations aimed at improving the quality and standard of life of the rural population [8] The transition to a qualitatively new employment structure should be preceded by the development of programs based on the socio-demographic characteristics of territories, the analysis of "bottlenecks" of employment, taking into account the need for effective use of raw materials and unique resources.

The creation of cooperative associations in the Republic is accompanied by significant difficulties related to the lack of proper state support, insufficient legal and regulatory framework, and imperfect organizational and economic mechanism of cooperation. In addition, in conditions of insufficient satisfaction of the needs of material and technical support of agricultural entities, there is an objective need to organize a wide network of servicing agricultural infrastructure through the service centers that are being created.

NCE "Atameken" has launched a pilot project in several regions to develop a cooperative chain in the village "from field to counter", three pilot regions have been identified - Almaty, Zhambyl and Turkestan, where regional project offices have been established. To Finance this project, 3 billion tenge was allocated from the state reserve, i.e. 1 billion tenge for each region. These funds will be used for lending to retail chains and producers, who will then purchase agricultural products from small peasant (farmer) and personal subsidiary farms for further processing and sale to consumers at an affordable (fixed) price. In Almaty region, the pilot project will be implemented through lending to major food producers [9]. Six manufacturing enterprises have been tentatively identified, which will be granted loans in the amount of 1 billion tenge for the further supply of 11 types of food products to retail facilities, which will ensure solid sales of up to $25 \%$ of the volume of products produced.

In Zhambyl region LLP "ORC "Zhambyl" and three of the commercial facility have been preliminary identified, which have 43 units of branch networks and retail outlets ("Breakfast basket" has 27 retailers, 3000 sqm warehouse space; network of large stores "Firkan" LLP has five retail chains, 1000 sq. $\mathrm{m}$ warehouse space; "Empire" has 11 social boutiques at the APC "Taraz"). Through these trading companies, it is planned to provide a loan for the purchase of 10 types of food products from domestic producers, which will ensure a solid sale of up to $23 \%$ of the volume of products produced by domestic producers. In the Turkestan region, eight producers have been tentatively identified, which will supply about 10 types of food products to retail facilities. In turn, small peasant (farm) and personal subsidiary farms will be financed under the "Enbek" program through the Fund for financial support of agriculture, 4.5 billion tenge has been reserved for this purpose.

Almost $80 \%$ of all investments are made through the "KazAgro" group of companies the main financing institution in agriculture in Kazakhstan, which includes three subsidiaries that Finance all sectors-from micro-loans to large business financing and leasing of agricultural machinery.

The holding company, as a state institution, attracts investors both on international and domestic markets, and attracts state funds. Every year, the amount of funding for innovative projects is growing, and in 2018, almost 85 projects worth almost 240 million Euros were commissioned. For investors, it is possible to obtain financing from a Kazakh Bank and provide a guarantee of the national holding "KazAgro" as collateral. In 2019, the total volume of investment in the agricultural sector of the country amounted to 1.1 billion USD, which is $41 \%$ more than in the previous year. Forecasts for activity in the agro-industrial sector suggest that it will attract about $\$ 10.3$ billion over the next five years [lk.8].

By the end of 2019, there are 49 farms that have implemented digital technologies (28 farms - in the direction of "precision" agriculture, 21-in dairy and meat farming). The economic effect of the introduction of digitalization elements amounted to 2.5 billion tenge $(+30 \%$ to production; - $20 \%$ of production costs). An increase in production was obtained and production costs were reduced by up to $20 \%$. A set of elements is formed to determine the level of farms, for example: in crop production, these are electronic field maps, navigation systems, and automatic management; in animal husbandry, there are milking machines with software, automatic systems for feeding water and feed, and systems for monitoring animal activity [lk.9].

Telematics elements in crop production include attachments for sowing complexes, combines and other equipment. More than 5 million hectares of land, or $20 \%$ of the total acreage is tilled by 1.5 thousand units of modern agricultural machinery. An increase in production was obtained and production costs were reduced by up to $20 \%$. Elements of digitalization are included in the existing mechanisms of public support. If the appropriate 


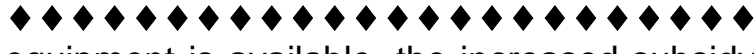

equipment is available, the increased subsidy rate is foreseen.

In Akmola region the digitalization of agricultural production is being implemented and from 2019 in the region the submission of applications and payment of grants is organized in electronic form via the web portal Minagro.kz. Rural producers don't need to apply themselves, everything is digitized. In the region the work on creation of electronic maps of fields is carried out, focused on the development of precision farming. In the region, 1,393 land users digitized fields on an area of 3006.1 thousand hectares, or $52.4 \%$ of the area subject to digitization. Three basic enterprises for the introduction of precision farming technologies were identified («AF Rodina» LLP Tselinogradsky district, «Belagash» LLP of Zhaksynsky district and «Zhuravlevka-1» LLP of Bulandinsky district) and three enterprises in animal husbandry that produce products using smart-farm technology ( $\mathrm{AF}$ Rodina» LLP in Tselinogradsky district, "Yessilagro» LLP in Burabaysky district and «Enbek» LLP in Akkol district).

A number of projects will be implemented to introduce digital technologies in crop production, online monitoring and accounting systems for field work using digital technologies and GPS equipment.

The introduction of digital technologies will make it possible to quickly make optimal decisions on field work, save fuel and lubricants, increase the efficiency of fertilizers and herbicides, which will generally contribute to the sustainable growth of agricultural production in rural areas [10].

\section{Conclusions}

1. The level of welfare of the rural population is determined by the employment of rural residents, the degree of participation of the able-bodied population in socially useful work.

2. It is necessary to take measures to reduce the outflow and create permanent qualified personnel by increasing wages and developing a competitive environment in rural areas.

3. The development of entrepreneurship in rural areas makes it possible to find ways to support the population for effective employment. At the same time, small business as a lever in solving a complex of economic and social problems: in saturating the market with goods and services, providing employment to the rural population by creating jobs, creating a competitive environment.
4. Digitalization in the crop and livestock sectors will make it possible to make effective decisions on field work, to save fuel and lubricants, to increase the efficiency of fertilizers and herbicides, and will lead to a steady increase in agricultural production in rural areas.

\section{References}

1 Akimbekova, Ch.U. Improving the wellbeing of the rural population of Kazakhstan / Ch.U. Akimbekova, Zh.S. Dosumova // Problems of AgriMarket. - 2019.-No. 3.- P.164-172.

2 Stoyanova, T.A. Research on social infrastructure of rural municipal areas: problems and methodology // Scientific and methodological electronic journal "Concent" [Electronic resource].- 2016.-URL: http: // www.e-koncept.ru/ 2016/86324.htm (date of access: 01.23.2020).

3 Bespaly, S.V. Influence of spatial factors on the development of suburban rural areas of Pavlodar region of the Republic of Kazakhstan / S.V. Bespaly // Problems of AgriMarket. - 2020. -№ 1. - P.164 - 170.

4 Bondarenko, L. Program - targeted approach to the development of rural areas / $\mathrm{L}$. Bondarenko // Agroindustrial complex: economics, management. - 2020. -No. 2.- P.47 - 62.

5 Stukach, V.F. Infrastructure: market institutions, rural social sphere, production / V.F. Stukach, L.V. Grishaeva, E.A. Astashova, V.S. Pecevich et-al.- Omsk: Publishing house of FS BOI VPU OmGAU P.A. Stolypin, 2015.- 276 p.

6 Shumakova, O.V. Sustainable development of rural areas: concept and essence / O.V. Shumakova, M.A. Rabkanova // Fundamental research. - 2014. - No. 8.-Part 7. - P. 1643-1646.

7 Dedkova, E. Actual aspects of food security / E. Dedkova, E.I. Korostelkina, O. Zhidova // Journal of Economic Research and Business Administration.- 2019.-T. 129.-No.3.-P. 172-183.

8 Activities of the "Fund for Financial Support of Agriculture" JSC [Electronic resource].2013-2019.- URL: http://www.kazagro.kz/web/ activities (date of access: 10.02.2020).

9 Kosymbayeva, Sh. I. Management of social infrastructure in the villages of the Republic of Kazakhstan / Sh.I. Kosymbayeva, N.A. Bencheva, Sh.E. Alpeisova, Zh.S. Bulkhairova // Bulletin of Karaganda University. Economic series. - 2020. - No. 1- P. 50 - 57.

10 Esina, Yu.L. Public support of AIC and rural development: foreign experience and domestic practice / Yu.L. Esina, N.M. Stepanenkova // Economy of agricultural and processing enterprises. -2019. - No. 5- P. 41-44.

\section{Information about authors:}

Kalykova Bakhyt, Candidate of Economic Science, Associated Professor, Kazakh National Agrarian Research University, Almaty, Kazakhstan, kalykova_b_b@mail.ru, http://orcid.org/0000-0001-8020-0392 